Kocaeli Journal of Science and Engineering

\title{
Variable-Speed Direct-Drive Permanent Magnet Synchronous Generator Wind Turbine Modeling and Simulation
}

\author{
Alper ULUTAȘ ${ }^{1, *}$ (D) H. Tark DURU² (iD) \\ ${ }^{1}$ Department of Electrical Engineering, Kocaeli University, Kocaeli, 41310, Turkey, Orcid Id: 0000-0002-7466-7161 \\ ${ }^{2}$ Department of Electrical Engineering, Kocaeli University, Kocaeli, 41310, Turkey, Orcid Id: 0000-0001-9887-8169
}

\begin{tabular}{ll} 
Article Info & \\
\hline & \\
Research paper & \\
Received : January 21, 2019 \\
Accepted $\quad$ April 30, 2019 \\
\\
Keywords \\
\hline Direct Drive \\
Pitch Control \\
PMSG \\
SVPWM \\
Wind Energy \\
Wind Turbine
\end{tabular}

\section{Introduction}

In recent years, the demand for energy has increased quickly with the increasing of the World population and the searches for new alternative energy sources instead of the decreasing fossil fuels has become a necessity besides their popularity. Renewable energy sources are cleaner and less harmful in terms of environmental aspects and, it is also known as Green Energy in literature. In Turkey, according to the ratio of the domestic production parts, the unit price of energy purchase has been increased and the investors and industrialists are encouraged in addition to the energy purchase guarantee with the Renewable Energy Resource Support Mechanism (YEKDEM). The wind energy is the kind of renewable energy, it is defined as in [1]; the sun is not being able to warm the atmosphere and the ground surface homogeneously. As a result, hot and cold air displaced and it caused flow in air by temperature and pressure difference.

The wind energy has been used to grind grain in mills, pump water, and generate electrical energy from past

\footnotetext{
* Corresponding Author: alperulutas@yahoo.com
}

to present. The speed of the wind and air density effectuates a kinetic energy in the wind and this kinetic energy is converted first to mechanical energy then electrical energy. Generally, energy conversion is made by wind turbine and generator, being the two indispensable main elements in energy conversion. In addition to these, wind farms are formed in such a way that the cost is most suitable considering the elements such as gearbox, converter, hydraulic unit, lubrication unit, cooling unit, transformer, etc. the requirement, advantages and disadvantages of the current conditions.

From past to present, some wind turbines have lost significance. These are; according to axis type, vertical axis turbines; according to speed, fixed speed turbines; according to generator type, Direct Current (DC) generators and squirrel cage induction generators (SCIG). Instead of them, according to axis type, horizontal axis turbine, according to speed, variable speed turbine; according to generator type, doubly fed induction generators (DFIG), wounded rotor induction generators (WRIG), wounded rotor synchronous generators (WRSG), and permanent magnet synchronous generators (PMSG) are used along with developing technology, it implements 
reduced costs and provided high performance and efficiency.

In this study, Direct Drive Permanent Magnet Synchronous Generator Wind Turbine was modeled and full scale Back-to-Back converter was controlled by Space Vector Pulse Width Modulation technique. Previous publications related to PMSG based variable speed wind turbine were mostly modeled by power coefficient. In fact, the turbine transmits torque to the generator and in this paper the modeling was done by torque equations instead of power and the results were verified to torque coefficient figure. Finally, the optimum torque control was implemented to assure that the tip speed ratio was constant and maximum at low wind speeds as well. By this means, the maximum power provided to grid will only depend on wind speed. This study was also supported by simulation results.

\section{System Modeling}

In this paper, Direct Drive PMSG Wind Turbine energy conversion principle scheme is shown in Figure 1.

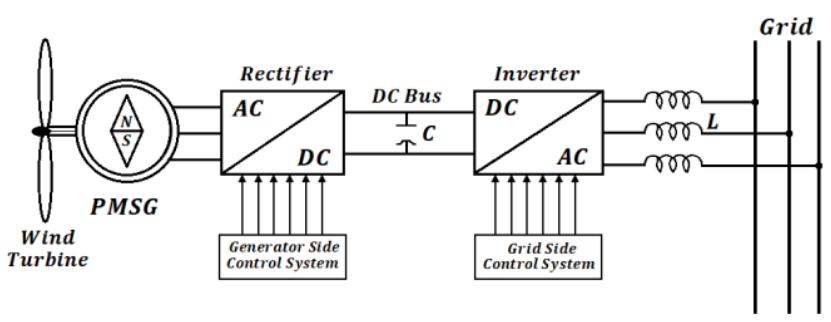

Figure 1. Direct drive permanent magnet synchronous generator wind turbine energy conversion principle scheme.

The PMSG used in the system is directly connected to wind turbine shaft without the gearbox, consequently gearbox losses and maintenance requirements are eliminated. The presence of permanent magnets instead of excitation windings in rotor of PMSG eliminates excitation losses in generator and it operates under high torque with its multi-pole structure and slow rotor speed. The control of magnetic flux cannot be carried out directly for the reason that the PMSG does not have an excitation winding such as wound rotor synchronous generators. Therefore, the control is made with full scale Back-to-Back power converters (DC bus existing) or matrix converters (DC bus not existing) designed as using improved semiconductor technologies.

The model of PMSG without damper winding has been developed on rotor reference frame using the following assumptions:

- Stator windings are sinusoidally distributed.

- The back-emf is sinusoidal.
- Eddy currents and hysteresis losses are negligible.

- Magnetic saturation is neglected.

While performing simulation, program MATLAB/ Simulink was utilized and "ode45" was used as the solution method.

\subsection{Direct-Drive Wind Turbine Model}

The power equation of wind because of kinetic energy rule due to movement of the wind is given as Eq. (1) $[2,3]$ :

$\mathrm{P}_{\text {wind }}=\frac{1}{2} \rho \mathrm{A} \mathrm{v}_{\text {wind }}{ }^{3}$

where; $\mathrm{P}_{\text {wind }}(\mathrm{W})$ wind power, $\rho\left(\mathrm{kg} / \mathrm{m}^{3}\right)$ air density, $\mathrm{A}\left(\mathrm{m}^{2}\right)$ swept area by blades, $\mathrm{v}_{\text {wind }}(\mathrm{m} / \mathrm{s})$ wind speed.

However, converting all of the power taken from the wind into mechanical power is not possible. According to Betz Limit, maximum efficiency of converting is defined in Eq. (2) as below [2, 4]:

$\mathrm{C}_{\mathrm{P}_{\max }}=\frac{16}{27}=0,59259=\% 59,26$

This equation identifies Betz Limit, and is shown as $C_{P}$ coefficient. $C_{P}$ value varies according to tip speed ratio and pitch angle and it is not a constant value. Therefore, the Eq. (3) is composed according to generated power by wind turbine by using Eq. (4):

$\mathrm{P}_{\text {turbine }}=\mathrm{C}_{\mathrm{P}}(\lambda, \beta) \frac{1}{2} \rho \mathrm{A} \mathrm{v}_{\text {wind }}{ }^{3}$

$\lambda=\frac{\mathrm{v}_{\text {linear }}}{\mathrm{v}_{\text {wind }}}=\frac{\omega_{\text {turbine }} \mathrm{r}}{\mathrm{v}_{\text {wind }}}=\frac{\frac{2 \pi \mathrm{n}}{60} \mathrm{r}}{\mathrm{v}_{\text {wind }}}$

where; $\lambda$ tip speed ratio, $\beta$ (degree) pitch angle, $v_{\text {linear }}(\mathrm{m} / \mathrm{s})$ linear velocity, $\omega_{\text {turbine }}(\mathrm{rad} / \mathrm{s})$ shaft angular speed, $\mathrm{n}(\mathrm{rpm})$ revolution per minute, $\mathrm{r}(\mathrm{m})$ blade length.

$\mathrm{C}_{\mathrm{P}}$ coefficient is calculated as in Eq. (5) by using Eq. (6) $[5,6]$ :

$\mathrm{C}_{\mathrm{P}}(\lambda, \beta)=\mathrm{C}_{1}\left(\frac{\mathrm{C}_{2}}{\gamma}-\mathrm{C}_{3} \beta-\mathrm{C}_{4}\right) \mathrm{e}^{-\frac{\mathrm{C}_{5}}{\gamma}}+\mathrm{C}_{6} \lambda$

$\gamma=\left(\frac{1}{\lambda+0,08 \beta}-\frac{0,035}{\beta^{3}+1}\right)^{-1}$

The mechanical torque generated by turbine is transmitted to generator. Thus, torque composes rotational movement in generator.

Torque equations are shown in Eq. (7), Eq. (8), Eq. (9), Eq. (10): 
$\mathrm{T}=\frac{\mathrm{P}}{\omega}$

$\mathrm{T}_{\text {turbine }}=\mathrm{C}_{\mathrm{P}}(\lambda, \beta) \frac{\frac{1}{2} \rho \mathrm{Av}_{\text {wind }}{ }^{3}}{\omega_{\text {turbine }}}$

$\mathrm{T}_{\text {turbine }}=\mathrm{C}_{\mathrm{P}}(\lambda, \beta) \frac{\frac{1}{2} \rho \mathrm{Av}_{\text {wind }}{ }^{3}}{\frac{\lambda \mathrm{v}_{\text {wind }}}{\mathrm{r}}}$

$\mathrm{T}_{\text {turbine }}=\frac{\mathrm{C}_{\mathrm{P}}(\lambda, \beta)}{\lambda} \frac{1}{2} \rho \mathrm{Ar} \mathrm{v}_{\text {wind }}{ }^{2}$

where; $\mathrm{T}_{\text {turbine }}(\mathrm{Nm})$ generated torque by wind turbine.

$\mathrm{C}_{\mathrm{P}}$ power coefficient can be expressed as $\mathrm{C}_{\mathrm{T}}$ torque coefficient. If an equation defines such as in Eq. (11):

$\mathrm{C}_{\mathrm{T}}=\frac{\mathrm{C}_{\mathrm{P}}}{\lambda}$

Obtained equation put into the Eq. (10) and rearranged in equation, the Eq. (12) can be acquired as:

$\mathrm{T}_{\text {turbine }}=\mathrm{C}_{\mathrm{T}}(\lambda, \beta) \frac{1}{2} \rho \mathrm{Ar}_{\mathrm{w}_{\text {wind }}}^{2}$

The parameters varied from $\mathrm{C}_{1}$ to $\mathrm{C}_{6}$ are design parameters of turbine and vary according to turbine. Figure 2 shows torque coefficient by various tip speed ratio and pitch angle.

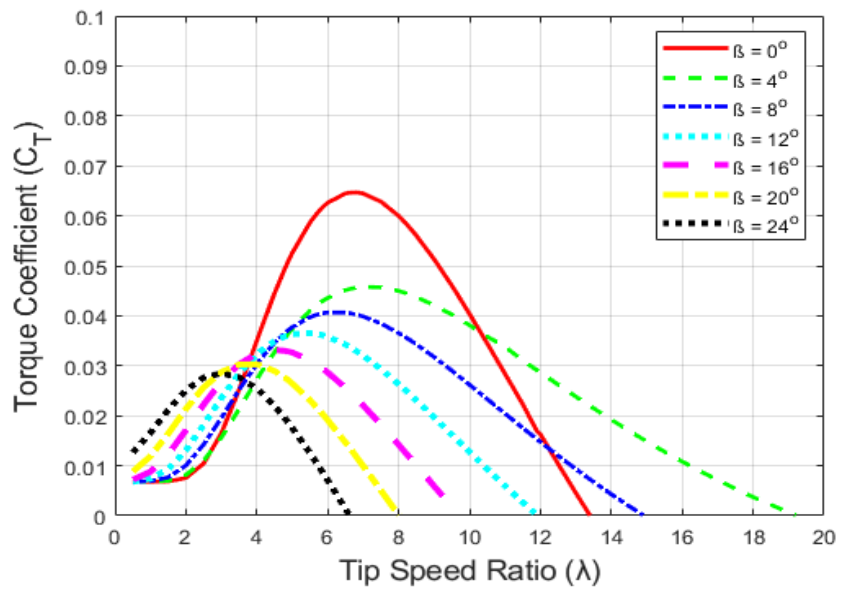

Figure 2. Tip speed ratio and torque coefficient according to pitch angle $\left(c_{1}=0,5176 ; c_{2}=116 ; c_{3}=0,4 ; c_{4}=5 ; c_{5}=\right.$ $\left.21 ; \mathrm{c}_{6}=0,0068\right)$.

\subsection{Permanent Magnet Synchronous}

\section{Generator}

The equations of PMSG in dq reference frame, obtained by park transformation are given in Eq. (13) and Eq. (14) by permanent magnets instead of excitation windings in the rotor [7]:
$\mathrm{U}_{\mathrm{d}}=\mathrm{Ri}_{\mathrm{d}}+\mathrm{L}_{\mathrm{d}} \frac{\mathrm{di}}{\mathrm{dt}}-\omega_{\mathrm{e}} \mathrm{L}_{\mathrm{q}} \mathrm{i}_{\mathrm{q}}$

$\mathrm{U}_{\mathrm{q}}=\mathrm{Ri}_{\mathrm{q}}+\mathrm{L}_{\mathrm{q}} \frac{\mathrm{di}_{\mathrm{q}}}{\mathrm{dt}}+\omega_{\mathrm{e}} \mathrm{L}_{\mathrm{d}} \mathrm{i}_{\mathrm{d}}+\omega_{\mathrm{e}} \phi_{\mathrm{r}}$

where; $\mathrm{U}_{\mathrm{d}}, \mathrm{U}_{\mathrm{q}}(\mathrm{V})$ stator $\mathrm{dq}$ reference frame voltages, $\mathrm{i}_{\mathrm{d}}$, $\mathrm{i}_{\mathrm{q}}$ (A) generator dq reference frame currents, $\mathrm{L}_{\mathrm{d}}, \mathrm{L}_{\mathrm{q}}(\mathrm{H})$ stator dq reference frame inductances, $\mathrm{R}(\Omega)$ stator resistance, $\omega_{\mathrm{e}}(\mathrm{rad} / \mathrm{s})$ electrical angular speed, $\phi \mathrm{r}(\mathrm{Vs})$ flux linkage.

Arranged electromagnetic torque of PMSG equation is given in Eq. (15) [7]:

$\mathrm{T}_{\mathrm{e}}=\frac{3}{2} \mathrm{p}\left(\phi_{\mathrm{r}} \mathrm{i}_{\mathrm{q}}+\left(\mathrm{L}_{\mathrm{d}}-\mathrm{L}_{\mathrm{q}}\right) \mathrm{i}_{\mathrm{d}} \mathrm{i}_{\mathrm{q}}\right)$

where; $\mathrm{T}_{\mathrm{e}}(\mathrm{Nm})$ electromagnetic torque, $\mathrm{p}$ pole pairs.

\section{System Controlling}

\subsection{Generator Side Converter Control}

The generator side converter transmits non-fixed frequency current generated in PMSG, into the DC bus. Therewithal, it controls the speed of rotor by field oriented control that provides high performance. Electromagnetic torque occurred in generator is generated by $I_{q}$ current which is transformed to $\mathrm{dq}$ reference frame by park transform.

The generator side converter $\mathrm{dq}$ frame reference voltages are given in Eq. (16) and Eq. (17):

$u_{d}^{*}=\left(k_{p}+\frac{k_{i}}{s}\right)\left(i_{d}^{*}-i_{d}\right)-\omega_{e} L_{q} i_{q}$

$u_{\mathrm{q}}^{*}=\left(\mathrm{k}_{\mathrm{p}}+\frac{\mathrm{k}_{\mathrm{i}}}{\mathrm{s}}\right)\left(\mathrm{i}_{\mathrm{q}}^{*}-\mathrm{i}_{\mathrm{q}}\right)+\omega_{\mathrm{e}} \mathrm{L}_{\mathrm{d}} \mathrm{i}_{\mathrm{d}}+\omega_{\mathrm{e}} \phi_{\mathrm{r}}$

The detailed concept of the used 6 pieces Insulated Gate Bipolar Transistors (IGBT) Back-to-Back converter of generator side is shown in Figure 3.

The Proportional Integral (PI) controller made closedloop control by fault current between generator current and reference current. The IGBTs are triggered by Space Vector Pulse Width Modulation (SVPWM) technique through obtained reference voltages. The parameters of PI controller are adjusted by tuning method.

\subsection{Optimum Torque Control}

The speed of rotor can be controlled by the optimum torque control. If inductance of generator where $\mathrm{L}_{\mathrm{d}}$ and $\mathrm{L}_{\mathrm{q}}$ are equal, the equation is expressed in Eq. (18): 
$\mathrm{T}_{\mathrm{e}}=\frac{3}{2} \mathrm{p} \phi_{\mathrm{r}} \mathrm{i}_{\mathrm{q}}$

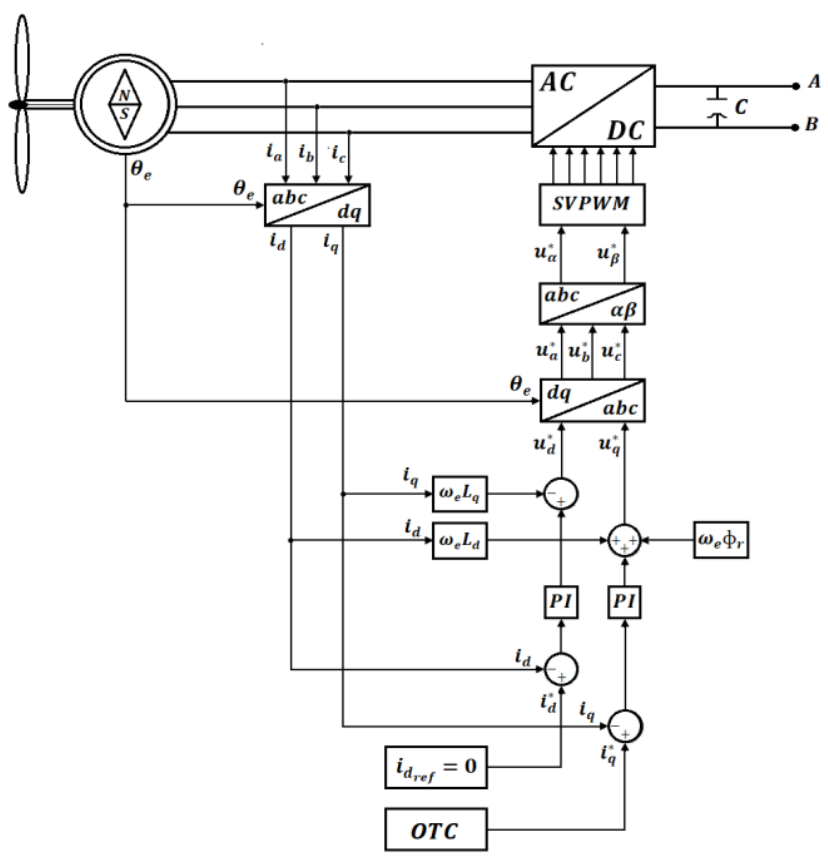

Figure 3. Generator side converter control scheme.

The electromagnetic torque in generator and $\mathrm{I}_{\mathrm{q}}$ current are linear between each other. $\mathrm{I}_{\mathrm{q}}$ reference current can be calculated by optimum torque control method.

With reference to this method, if the tip speed ratio is chosen as optimum, the value of $\mathrm{C}_{\mathrm{T}}$ torque coefficient can be achieved. Herewith, the constant values for turbine are obtained and it is given as $\mathrm{K}_{\mathrm{opt}}$ constant in Eq. (19) [8]:

$\mathrm{K}_{\mathrm{opt}}=\frac{1}{2} \frac{\mathrm{C}_{\mathrm{T}}\left(\lambda_{\mathrm{opt}}, \beta\right) \rho \pi \mathrm{r}^{5}}{\lambda_{\mathrm{opt}}{ }^{2}}$

If the requirement arranges are done, the following Eq. (20) can be obtained:

$\mathrm{T}_{\mathrm{opt}}=\mathrm{K}_{\mathrm{opt}} \omega_{\text {turbine }}^{2}$

where; $\mathrm{T}_{\text {opt }}(\mathrm{Nm})$ optimum torque.

If the optimum torque and occurred electromagnetic torque in generator are equalized, $\mathrm{I}_{\mathrm{q}}$ reference current can be acquired.

\subsection{Pitch Control}

The shaft of wind turbine must rotate in a permitted speed range to avoid mechanical stresses and damages in turbine and generator. Such as seen in Figure 4 the turbine operates between cut-in speed and rated wind speed at partial power, and it operates at full power between rated wind speed and cut-off speed. The turbine is at stand-by position when wind speed is less than cut-in speed and higher than cut-off speed. Generally the pitch angle of blades is 0 degree when the turbine is parking. The pitch angle varies when the wind speed is higher than rated wind speed in order to protects the turbine, and the rotor speed becomes stable [9].

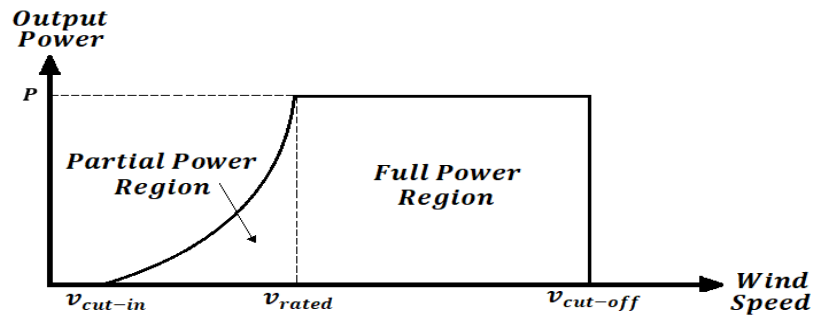

Figure 4. Power curve and pitch control according to wind speed.

\subsection{Grid Side Converter Control}

The generator side converter, converts DC voltage to grid frequency and Alternative Current (AC) voltage of grid, and it provides active and reactive power to grid. In the meantime, DC bus voltage is fixed by voltage oriented control.

The output voltages of converter dq reference frame equations are given in Eq. (21) and Eq. (22):

$\mathrm{U}_{\mathrm{d}}=\mathrm{V}_{\mathrm{d}}+\mathrm{Ri}_{\mathrm{d}}+\mathrm{L} \frac{\mathrm{di}}{\mathrm{dt}}-\omega \mathrm{Li}_{\mathrm{q}}$

$\mathrm{U}_{\mathrm{q}}=\mathrm{V}_{\mathrm{q}}+\mathrm{Ri}_{\mathrm{q}}+\mathrm{L} \frac{\mathrm{di}_{\mathrm{q}}}{\mathrm{dt}}+\omega \mathrm{Li}_{\mathrm{d}}$

where; $\mathrm{U}_{\mathrm{d}}, \mathrm{U}_{\mathrm{q}}(\mathrm{V}) \mathrm{dq}$ reference frame converter output voltages, $i_{d}, i_{q}(A) d q$ reference frame converter output currents, $\mathrm{V}_{\mathrm{d}}, \mathrm{V}_{\mathrm{q}}(\mathrm{V}) \mathrm{dq}$ reference frame grid voltages, $\mathrm{R}(\Omega)$ resistance of grid-transformer-filter, L $(\mathrm{H})$ inductance of grid-transformer-filter, $\omega(\mathrm{rad} / \mathrm{s})$ angular frequency of grid.

The provided active and reactive power can be shown as Eq. (23) and Eq. (24):

$\mathrm{P}_{\text {out }}=\frac{3}{2} \mathrm{~V}_{\mathrm{d}} \mathrm{i}_{\mathrm{d}}=\mathrm{V}_{\mathrm{dc}} \mathrm{I}_{\mathrm{dc}}$

$\mathrm{Q}_{\text {out }}=-\frac{3}{2} \mathrm{~V}_{\mathrm{d}} \mathrm{i}_{\mathrm{q}}$

where; $\mathrm{P}_{\text {out }}(\mathrm{W})$ provided active power to grid, $\mathrm{Q}_{\text {out }}(\mathrm{VAr})$ provided reactive power to grid, $\mathrm{V}_{\mathrm{dc}}(\mathrm{V}) \mathrm{DC}$ bus voltage, $I_{d c}(A)$ DC bus current.

This provides active and reactive power to grid, through under controlling stability of DC bus [10].

The grid side of space vector PWM voltage control strategy is shown as follow in Eq. (25-26): 
$u_{d}^{*}=\left(k_{p}+\frac{k_{i}}{s}\right)\left(i_{d}^{*}-i_{d}\right)-\omega L i_{q}+V_{d}$

$u_{q}^{*}=\left(k_{p}+\frac{k_{i}}{s}\right)\left(i_{q}^{*}-i_{q}\right)+\omega L i_{d}$

The parameters of grid are given in Table A.2 as appendix and the detailed concept of Back-to-Back converter used 6 pieces IGBTs of grid side is shown Figure 5.

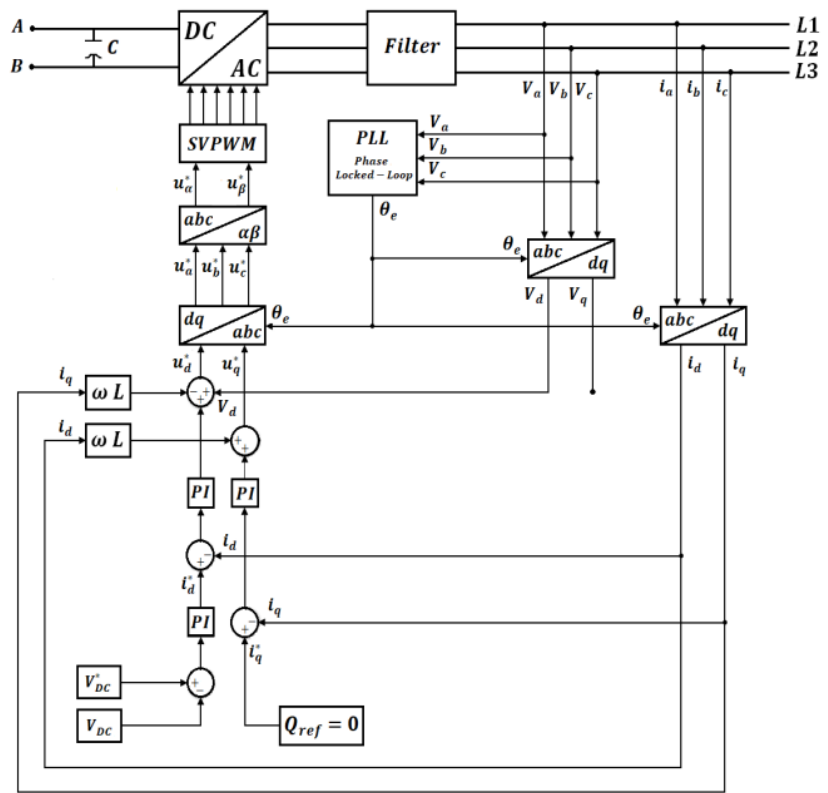

Figure 5. Detailed concept of grid side converter control scheme.

The PI controller is alike the generator side control, it made closed-loop control by fault current between generator current and reference current. The IGBTs are triggered by SVPWM technique through the obtained reference voltages. The parameters of PI controller are adjusted by tuning method.

\section{Simulation Results}

As a result of researches and investigations, the $800 \mathrm{~kW}$ wind turbine was designed and simulated as parameters of blade which are, length $\mathrm{R}=30 \mathrm{~m}$, maximum power coefficient $C_{P \max }=0.44$, tip speed ratio $\lambda_{\max }=6.9$.

As can be seen in Figure 6, the simulation has been started at initial value of $\mathrm{v}_{\text {rated }}=10.3 \mathrm{~m} / \mathrm{s}$ which is nominal wind speed and then wind speed was increased to $13 \mathrm{~m} / \mathrm{s}$. After a few seconds, it was decreased to $7 \mathrm{~m} / \mathrm{s}$ from 13 $\mathrm{m} / \mathrm{s}$, then after a while it was increased to $10.3 \mathrm{~m} / \mathrm{s}$ again.

The shaft speed is fixed by pitch control at wind speed larger than the nominal wind speed in Figure 7. In Figure 8 , when the actual speed of turbine is lower than nominal wind speed, the power coefficient is fixed at
$\mathrm{C}_{\mathrm{P}}=6.9$ by the optimum torque control method and the power obtained from the turbine is only dependent on the wind speed, this means Maximum Power Point Tracking (MPPT) control is performed with optimum torque control.

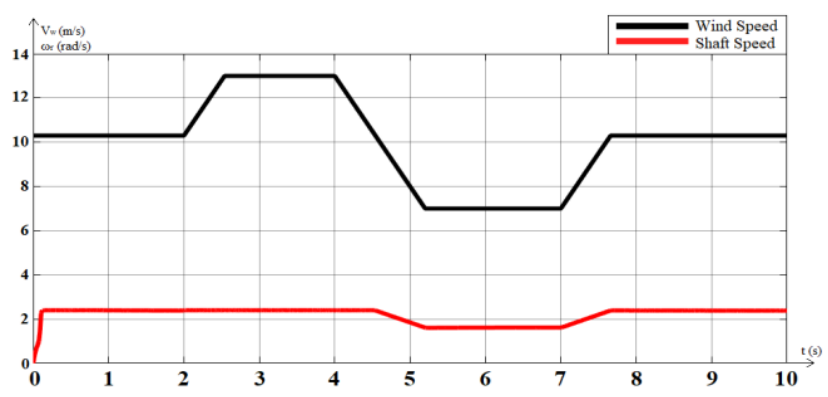

Figure 6. Wind speed and shaft speed.

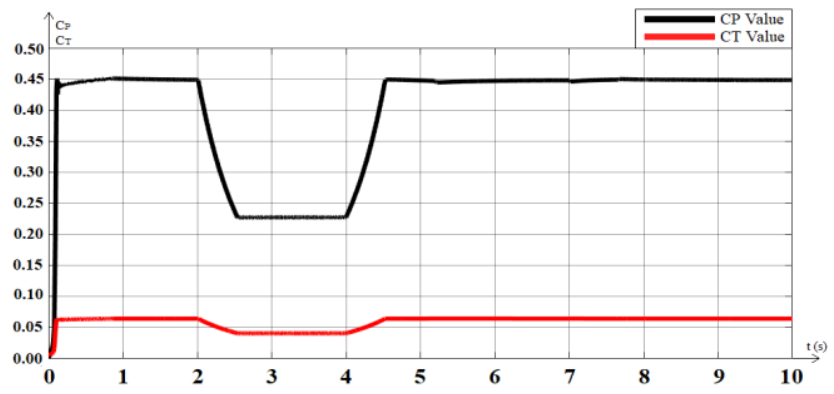

Figure 7. $C_{P}$ and $C_{T}$ values.

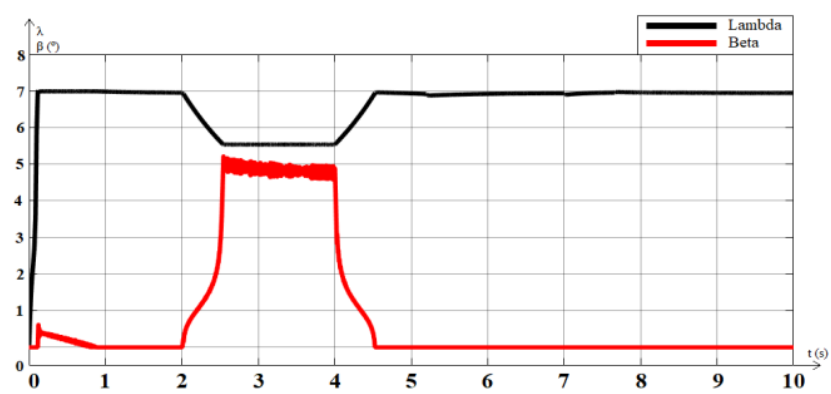

Figure 8. Tip speed ratio and pitch angle.

The graphic of the electromagnetic torque in generator is shown in Figure 9. In generator mod operate of machine, the electromagnetic torque is less than zero (0), for easy understanding in Figure 9, this value was multiplied with minus one $(-1)$.

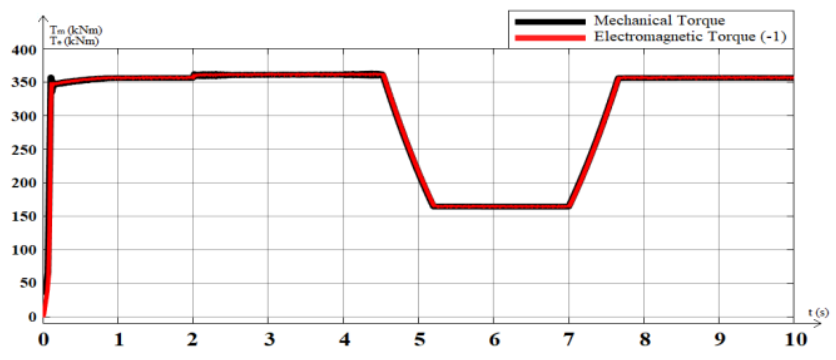

Figure 9. Mechanical torque and electromagnetic torque. 
Figure 10 shows that the voltage of DC busbar is fixed at the reference voltage of $1200 \mathrm{~V}$. When the wind speed varies, DC voltage is a little bit fluctuated but as seen in Figure 11, the provided active power to grid is not fluctuated due to the charging/ discharging of capacitor.

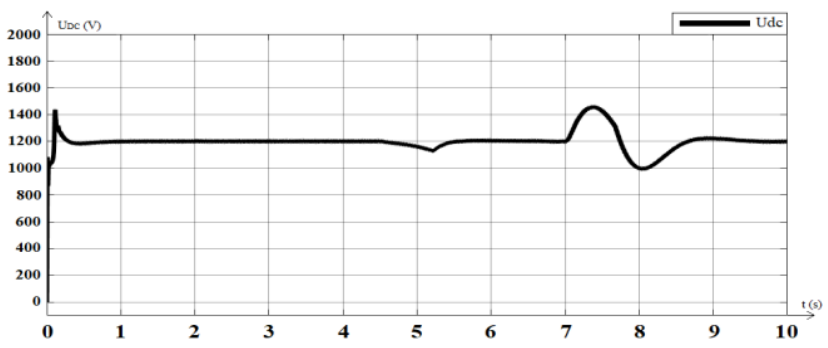

Figure 10. DC bus voltage.

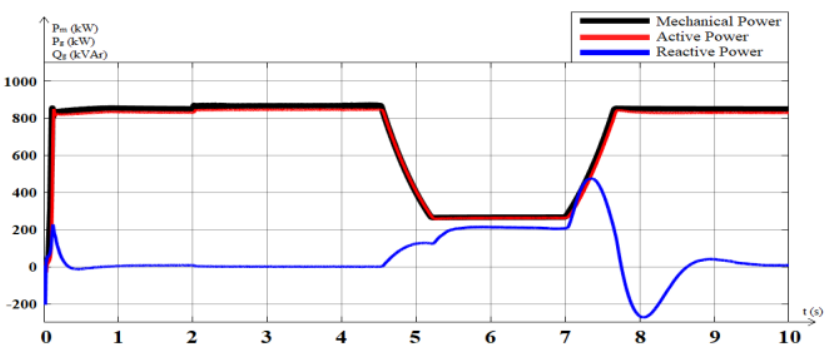

Figure 11. Mechanical power, provided active and reactive power to grid.

In Figure 12, three phase currents and dq currents of generator are given for first 0.5 second. Likewise, current and voltage of phase A belonging to converter and grid are given in Figure 13 and Figure 14 for first 0.5 second.

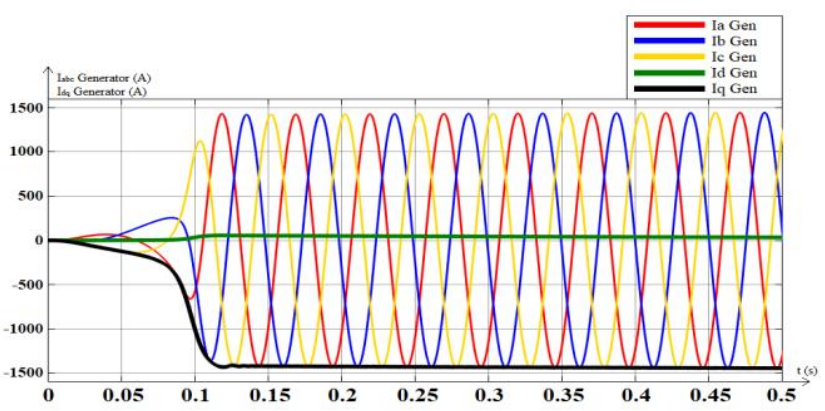

Figure 12. Generator three-phase currents and dq reference currents.

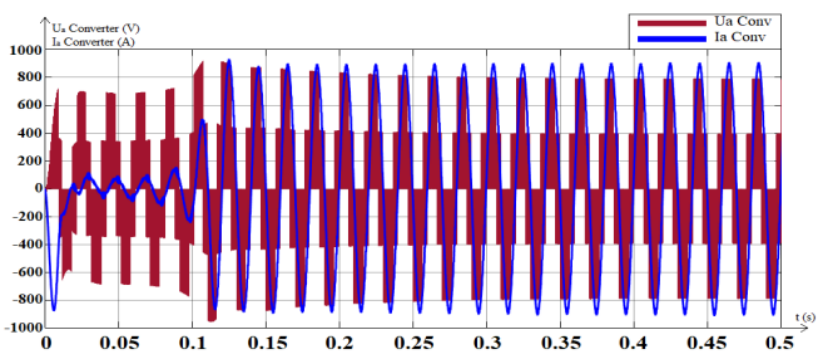

Figure 13. Phase-A current and voltage output of converter.

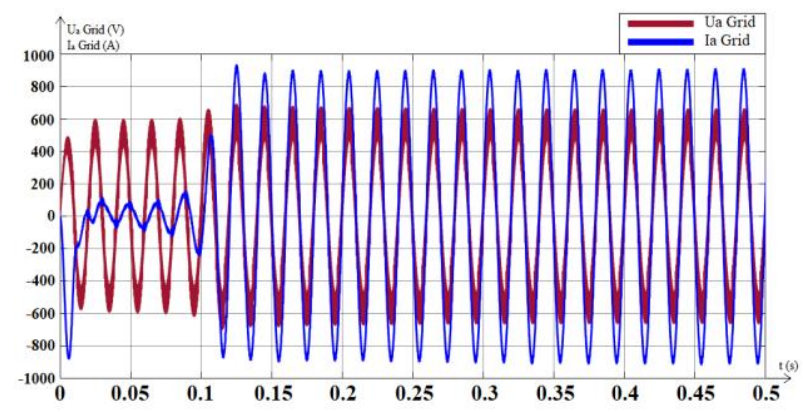

Figure 14. Phase-A provided current and voltage to grid.

As a result, the active power provided by turbine to grid is stable and the maximum power is obtained from the existing wind.

\section{Conclusions}

In this paper, the Variable-Speed Direct-Drive PMSG Wind Turbine connected to grid, was modeled as mathematical and controlled by converter. The voltages and the currents of the generator and grid was transformed to $\mathrm{dq}$ reference frame by park transforms. Thus, the equations of generator and grid were simplified. Simulation was performed at different wind speeds in order to show the system response. With method of optimum torque control, the shaft speed decelerated at low wind speed of rated wind speed. In this way the tip speed ratio was kept optimum, then turbine provided maximum power. The simulation results show that accuracy of the model, and applicability of the control system.

\section{References}

[1] T.C. Enerji ve Tabii Kaynaklar Bakanlığı, Enerji İşleri Genel Müdürlüğü, Yenilenebilir Enerji, Rüzgar Enerjisi Nedir?, http://www.yegm.gov.tr/ yenilenebilir/ruzgar-ruzgar_enerjisi.aspx (Access Date:21.01.2019).

[2] Ragheb M., Ragheb A. M., 2011. Wind Turbine Theory - The Betz Equation and Optimal Rotor Tip Speed Ratio. Fundamental and Advanced Topics in Wind Power (Editor: Carriveau R.), InTechOpen, pp. 19-38, doi: $10.5772 / 731$.

[3] Ackermann T., 2005. Wind Power in Power Systems, pp. 33-34, John Wiley and Sons, West Sussex, England.

[4] Çetin N. S., Yurdusev M. A., Ata R., Özdamar A., 2005. Assessment of Optimum Tip Speed Ratio of Wind Turbines. Mathematical and Computational Applications, 10(1), pp.147-154. 
[5] Kumsuwan Y., Jansuya P., 2013. Design of MATLAB/Simulink Modeling of Fixed-Pitch Angle Wind Turbine Simulator. 10th Eco-Energy and Materials Science and Engineering, Muang, UbonRatchathani, Thailand, 5-8 December, pp.362-370.

[6] Gürkaynak Y., 2006. Modeling and Control of Variable-Speed Direct-Drive Wind Power Plant. M.Sc. Thesis, Istanbul Technical University, İstanbul.

[7] Wang C. N., Lin W. C., Le X. K., 2014. Modelling of a PMSG Wind Turbine with Autonomous Control. Mathematical Problems in Engineering, 2014, doi: $10.1155 / 2014 / 856173$.

[8] Linus R. M., Damodharan P., 2015. Maximum Power Point Tracking of PMSG based Grid Connected WECS using Quadrature Axis Current. 4th International Conference on Renewable Energy Research and Applications, Palermo, Italy, 22-25 November, pp. 671-676.

[9] Smida M. B., Sakly A., 2015. Pitch Angle Control for Variable Speed Wind Turbines. Journal of Renewable Energy and Sustainable Development (RESD), 1(1) pp. 81-88.

[10] Bin Q., Xuexiang J., Yulin Z., Qing T., 2014. The Maximum Power Control of Direct-Drive Wind Turbine. 26th Chinese Control and Decision Conference (CCDC), Changsha, China, 31 May - 2 June, pp. 4834-4839.

[11] Pidiiti T., Tulasi Ram Das G., 2017. Power Maximization and Control of PMSG Wind Energy System without Wind Speed Sensors. International Journal of Control Theory and Applications, 10, pp. 253-260.

[12] Hemeida A. M., Farag W. A., Mahgoub O. A., 2011. Modeling and Control of Direct Driven PMSG for Ultra Large Wind Turbines. International Journal of Energy and Power Engineering, 5(11), pp. 12691275 .

[13] Wu Z., Dou X., Chu J., Hu M., 2013. Operation and Control of a Direct-Driven PMSG-Based Wind Turbine System with an Auxiliary Parallel Grid-Side Converter. Energies, 6, pp. 3405-3421.

[14] Hao H., Bo G., Yan R., Hui H., 2015. Simulation and Analysis of Direct-driven Wind Turbine. International Journal of Online Engineering (iJOE), 11(5), pp. 17-23.

\section{Appendices}

Table A.1. Parameters of PMSG.

\begin{tabular}{|l|c|c|r|}
\hline \multicolumn{1}{|c|}{ Parameters } & Symbol & Unit & Value \\
\hline Rated Rotational Speed & $\mathrm{n}$ & $\mathrm{rpm}$ & 18 \\
\hline Maximum Rotational Speed & $\mathrm{n}_{\max }$ & $\mathrm{rpm}$ & 21,6 \\
\hline Rated Electrical Frequency & $\mathrm{f}_{\mathrm{n}}$ & $\mathrm{Hz}$ & 15,6 \\
\hline Number of Phases & - & - & 3 \\
\hline Connection Type & - & - & STAR \\
\hline Rated Apparent Power & $\mathrm{S}_{\mathrm{n}}$ & $\mathrm{kVA}$ & 1036 \\
\hline Rated Load Voltage & $\mathrm{V}_{\mathrm{n}}$ & $\mathrm{V}$ & 591 \\
\hline RMS Phase Current (line) & $\mathrm{I}_{\mathrm{n}}$ & $\mathrm{A}$ & 1012 \\
\hline Open Circuit Voltage (line) & - & $\mathrm{V}$ & 565 \\
\hline Inductance (phase) & $\mathrm{L}$ & $\mathrm{mH}$ & 1,98 \\
\hline Resistance (ph/ph) & $\mathrm{R}$ & $\mathrm{m} \Omega$ & 13 \\
\hline Rated Power Factor & $\mathrm{Cos}(\varphi)$ & - & 0,82 \\
\hline Rated Efficiency & $\eta$ & - & 0,94 \\
\hline Flux Linkage & $\Phi$ & $\mathrm{Wb}$ & 3,123 \\
\hline
\end{tabular}

Table A.2. Parameters of grid.

\begin{tabular}{|l|c|c|r|}
\hline \multicolumn{1}{|c|}{ Parameters } & Symbol & Unit & Value \\
\hline Voltage $(\mathrm{ph} / \mathrm{ph})$ & $\mathrm{V}_{\text {grid }}$ & $\mathrm{V}$ & 690 \\
\hline Frequency & $\mathrm{F}_{\text {grid }}$ & $\mathrm{Hz}$ & 50 \\
\hline Inductance & $\mathrm{L}_{\text {grid }}$ & $\mathrm{mH}$ & 0,3466 \\
\hline Resistance & $\mathrm{R}_{\text {grid }}$ & $\Omega$ & 0,0662 \\
\hline Filter Inductance & $\mathrm{L}_{\text {filter }}$ & $\mathrm{mH}$ & 1,1 \\
\hline
\end{tabular}

